\title{
Prevalence of Smear Positive Tuberculosis, Intestinal Parasites and Their Co-Infection among Tuberculosis Suspects in Gondar University Hospital and Gondar Poly Clinic, North West Ethiopia
}

\author{
Martha Alemayehu*, Wubet Birhan², Yeshambel Belyhun², Mezgebu Sahle ${ }^{3}$ and Belay Tessema
}

${ }^{1}$ Department of Medical Microbiology, School of Biomedical and Laboratory Sciences, University of Gondar, Ethiopia

${ }^{2}$ Department of Immunology and Molecular Biology, School of Biomedical and Laboratory Sciences, University of Gondar, Ethiopia

${ }^{3}$ School of Law, University of Gondar, Ethiopia

\begin{abstract}
Background: The high prevalence of intestinal parasites indicated an increased morbidity in TB patients and emphasized the importance of continued stool analysis and treatment. Reducing the morbidity and mortality of TB and intestinal parasitosis co-infected persons requires an improved understanding of the prevalence of TB, intestinal parasites and their co-infection.
\end{abstract}

Objectives: This study determines the prevalence of Smear positive tuberculosis, intestinal parasites and their co-infection among tuberculosis suspects in Northwest Ethiopia.

Methods: A cross sectional study was conducted from March 2008-May 2008 among four hundred and fifteen tuberculosis suspects. Socio-demographic and clinical data was collected using structured questionnaire. Spot morning spot sputum sample were collected for direct AFB microscopy, and stool samples for direct saline microscopy and formol-ether concentration technique. Statistical analysis was performed using SPSS Version 16.0 software packages. Pearson chi-squared test, odds ratio and $95 \%$ confidence interval were used to measure the strength of an association. A p-value of $<0.05$ was considered statistically significant.

Results: The mean age the participants were 35.72 years for both sexes. Smear positive tuberculosis and intestinal parasites were diagnosed in $72(17.3 \%)$ \& $120(28.9 \%)$ of the study subjects, respectively. Intestinal parasites were detected in $24(33.3 \%)$ of smear positive tuberculosis patients. Hookworm and Strongyloides stercolaries infection were common in smear positive tuberculosis patients, with prevalence of $8(11.1 \%)$ and $5(6.9 \%)$, respectively. Smear positive TB patients were frequently co-infected with parasitic infection $(X 2=28.148$, $p=0.154)$ that will increase morbidity. Tuberculosis had significant association with shoe wearing $(p=0.038)$ and finger nail $(p=0.039)$. Bacillus Calmat and Guerin vaccination was also strongly associated with pulmonary tuberculosis infection $(\mathrm{OR}=0.262 ; 95 \% \mathrm{Cl}, 0.126-0.545, \mathrm{p}=0.00)$.

Conclusion: The prevalence of smear positive tuberculosis and intestinal parasitosis co-infection predominantly Hookworm is relatively higher among tuberculosis suspects that may increase morbidity, so all tuberculosis suspects should be checked for parasitic infection and be treated accordingly.

Keywords: Smear positive tuberculosis; Bacillus Calmat and Guerin; Intestinal parasites; Northwest Ethiopia

\section{Background}

Tuberculosis (TB) continues to be the most important causes of morbidity and mortality worldwide, and caused mainly by Mycobacterium tuberculosis [1,2]. Based on the World Health Organization (WHO) estimates, 8.8 million new cases of TB and 1.1 million deaths occurred globally in 2010 [1]. The incidence of tuberculosis has been increasing dramatically throughout the world in the last decade. According to the Ministry of Health Hospital statistics data, TB is one of the leading cause of morbidity, the fourth cause of hospital admission, and the second cause of hospital death in Ethiopia [3].

The high rate of chronic malnutrition, widespread poverty, overcrowding, and high sero-prevalence of HIV infection has created an environment which made TB a formidable threat in Ethiopia [3]. Most patients with TB but without other illnesses absorb antimycobacterial drugs reliably $[4,5]$. The degrees of malabsorption appear to differ across populations [6-9].

Intestinal parasitic infections are among the most common infections in the world, being responsible for considerable morbidity and mortality [10-12]. Intestinal helminthes are estimated to account for the infection of over 1,400 million people globally and are among the most important health problems in the world, particularly in the developing countries [13]. Intestinal helmenthic infections, such as ascariasis, trichuriasis and hook worm infections are also prevalent in Ethiopia [14]. The wide distribution of intestinal helminthiasis in Ethiopia is attributed to low socio-economic status and poor sanitation [15].

Over one third of the human population is currently infected with

*Corresponding author: Dr. Martha Alemayehu, Department of Medical Microbiology, University of Gondar, Gondar, Ethiopia, Tel: +251-918-776920; E-mail: marthialex2011@gmail.com; yeshmebetessey@gmail.com

Received April 02, 2014; Accepted April 18, 2014; Published April 25, 2014

Citation: Alemayehu M, Birhan W, Belyhun Y, Sahle M, Tessema B (2014) Prevalence of Smear Positive Tuberculosis, Intestinal Parasites and Their CoInfection among Tuberculosis Suspects in Gondar University Hospital and Gondar Poly Clinic, North West Ethiopia. J Microb Biochem Technol 6: 179-184. doi:10.4172/1948-5948.1000140

Copyright: () 2014 Alemayehu M, et al. This is an open-access article distributed under the terms of the Creative Commons Attribution License, which permits unrestricted use, distribution, and reproduction in any medium, provided the original author and source are credited 
Citation: Alemayehu M, Birhan W, Belyhun Y, Sahle M, Tessema B (2014) Prevalence of Smear Positive Tuberculosis, Intestinal Parasites and Their Co-Infection among Tuberculosis Suspects in Gondar University Hospital and Gondar Poly Clinic, North West Ethiopia. J Microb Biochem Technol 6: 179-184. doi:10.4172/1948-5948.1000140

M. tuberculosis, and a similar percentage with helminths, the majority of these infections are found in the developing countries [16-18]. Mycobacterium tuberculosis usually enters the host through inhalation of droplets containing viable bacteria. The bacterium reaches alveolar spaces and is ingested by alveolar macrophages [19]. This results in the induction of inflammatory responses with the consequent development of a glaucomatous lesion [20] where different T-cell populations participate in protective immune responses [21].

Infection with intracellular parasites such as Mycobacterium tuberculosis induces Th1 immune response whereas intestinal parasites, mainly helminthes, elicit Th2 immune response. In sub Saharan Africa, where the prevalence of parasitic infections is very high, a dominant Th2 polarized immune response has been reported [22] and suggested to increase susceptibility to $M$. tuberculosis. Chronic helminthes infection can affect the ability of the host to control mycobacterial infections [23]. Co-infection also hastens progression of their disease [24-26].

The high prevalence of intestinal parasites indicated an increased morbidity in TB patients and emphasized the importance of continued stool analysis and treatment [27]. Reducing the morbidity and mortality of TB and intestinal parasitosis co-infected persons requires an improved understanding of the prevalence of $\mathrm{TB}$, intestinal parasites and their co-infection among tuberculosis suspects. Both TB and parasitic infections have been studied extensively, but information is scarce regarding the level of $\mathrm{TB}$ and parasitosis co-infection in co-endemic regions. Therefore, this study aimed to determine the prevalence of smear positive tuberculosis, intestinal parasitosis and their co-infection among tuberculosis suspected patients to generate useful information of public health importance.

\section{Materials and Methods}

\section{Study setting}

The study was conducted at Gondar University Hospital and Poly Clinic in Gondar town. Gondar is located $742 \mathrm{~km}$ far from Addis Ababa to the North West Ethiopia. Its elevation is 2,200 $\mathrm{m}$ above sea level. The hospital is a tertiary level teaching and referral hospital with 400 beds for inpatients, and renders referral health services to over 5 million inhabitants and also Poly clinic is a health center gives health services to many peoples in Gondar town, North West Ethiopia.

\section{Study design and participants}

A cross-sectional study was conducted from March, 2008 to May, 2008 at Gondar University Hospital and Poly Clinic in Gondar town. A total of $415 \mathrm{~TB}$ suspects attending Gondar University Hospital laboratory and poly clinic laboratory for microscopic examination of sputum for Acid fast bacilli (AFB) were enrolled in this study. An individual with cough of two weeks or more were considered as TB suspect.

\section{Study population}

All individuals with cough of two weeks or more visiting Gondar University Hospital and poly clinic were included whereas, individuals already started anti-TB treatment, with severe illness \& unable to provide sputum sample were excluded.

\section{Socio-demographic data collection}

Socio-demographic and other information with known risk factors were collected using a structured questionnaire by doctors through interview during the patient visit and Bacillus Calmat and Guerin (BCG) vaccination status was observed by nurses using the presence of BCG scar as an indicator from all study subjects. The presence or absence of a BCG scar is often used as an indicator of previous vaccination in clinical settings as well as surveys performed by health institutions such as the Expanded Program on Immunization to assess vaccine uptake [28].

\section{Sputum sample collection and processing}

Spot morning spot sputum was collected from all study participants and the sample was delivered to the Gondar Hospital bacteriology laboratory and to the poly clinic laboratory for microscopic examination using conventional Ziehl-Neelsen staining method. A smear was prepared and dried, then heat-fix the dried smear, cover the smear with carbol fuchsin stain, heat the stain until vapor just begins to rise and wait for 5 minute. Then wash off the stain with clean water, cover the smear with $3 \% \mathrm{v} / \mathrm{v}$ acid alcohol for 3 minute and wash with clean water, cover the smear with methylene blue stain for 1 minute and wash off the stain with clean water. Finally wipe the back of the slide clean, airdry and the stained slides were examined microscopically using oilimmersion objective for AFB.

\section{Stool specimen collection and processing for parasite examination}

The appropriate amount of stool sample was collected from all study participants and delivered to the Gondar Hospital Parasitology laboratory and to the poly clinic laboratory for parasitic examination using direct saline microscopic method and formal-ether concentration technique. For direct saline method an applicator stick was used to mix about $50 \mathrm{mg}$ of faeces with one or two drops of normal saline placed on a clean slide. A uniform thin suspension was made and cover with cover slip. The entire film was screened systematically for the presence of helminth ova and larvae or protozoan cysts and trophozoites. In addition, using an applicator stick about $1 \mathrm{~g}$ of faeces was placed in a clean $15 \mathrm{ml}$ conical centrifuge tube containing $7 \mathrm{ml}$ formalin saline for formal-ether concentration technique. The resulting suspension was filtered through a sieve into another conical centrifuge tube. The debris trapped on the sieve was discarded. After adding $3 \mathrm{ml}$ of diethyl ether to the formalin solution, the contents were centrifuged at 3, 200 rpm for 3 minutes. The supernatant was poured away and the tube was replaced in its rack. Smear of the sediment was made on clean glass slide and covered by cover slip. Then, the entire area under the cover slip was systematically examined using 10x and 40x objective lenses.

\section{Data processing and analysis}

Data was entered and analyzed using SPSS version 16 statistical program. Simple descriptive statistics was used to explain sociodemographic, prevalence rate of smear positive TB, intestinal parasite and their co-infection. Chi-squared test was used to compare the study variables for the presence or absence of association in all cases. Odds ratio and $95 \%$ confidence interval were used to measure the strength of an association. A P-value of $<0.05$ was considered indicative of a statistically significant difference.

\section{Ethical consideration}

Ethical approval for the study was obtained from the ethics review board of the University of Gondar, College of Medicine and Health Sciences. Permission to conduct the study was also obtained from 
Citation: Alemayehu M, Birhan W, Belyhun Y, Sahle M, Tessema B (2014) Prevalence of Smear Positive Tuberculosis, Intestinal Parasites and Their Co-Infection among Tuberculosis Suspects in Gondar University Hospital and Gondar Poly Clinic, North West Ethiopia. J Microb Biochem Technol 6: 179-184. doi:10.4172/1948-5948.1000140

Gondar University Hospital and Gondar Poly Clinic administrators. Informed verbal consent was obtained from each study participants. Any information obtained at each course of the study was kept confidential.

\section{Results}

\section{Socio-demographic characteristics}

The study comprised 415 TB suspects (232 males and 183 females). The age range of the study participants was between 2 and 80 years and with a mean age of 35.72 years. Among the study participants, $53.5 \%$ were married and the proportion of urban vs. rural was $36 \%$ whereas monthly income $<200$ birr and participants using pipe water source comprised $41.9 \%$, and $41.0 \%$, respectively. BCG vaccination status showed that 130 (31.3\%) of the study subjects had been vaccinated with BCG. Among the vaccinated participants $9(6.9 \%)$ were smear positive for TB (Table 1).

\section{Prevalence of Smear Positive TB and Associated Risk Factors among TB Suspects}

Out of $415 \mathrm{~TB}$ suspects enrolled in the study, 72 (17.3\%) were smear positive for AFB (smear positive TB) whereas 343 (82.7\%) were smear negative for AFB. Tuberculosis had significant association with shoe wearing $(p=0.038)$, finger nail $(p=0.039)$ and $B C G$ vaccination $(\mathrm{p}=0.00)$.

BCG vaccination was strongly associated with TB infection $(\mathrm{OR}=0.262 ; 95 \% \mathrm{CI}, 0.126-0.545)$. However, there was no evidence of significant association with sex $(\mathrm{p}=0.396)$ and residence area of the patients $(\mathrm{p}=0.290)($ Table 2).

\section{Prevalence of Intestinal Parasites and Risk Factors among TB Suspects}

Out of the 415 TB suspects, 295 (71.1\%) had no intestinal parasites, whereas 120 (28.9\%) had intestinal parasites with Ascaris lumbricoides accounting for the overwhelming majority 32 (7.7\%). Mixed parasitic infections was observed in $17(4.1 \%)$ of the study groups (Table 3 ). The prevalence of intestinal parasitic infection for male was 1.14 times than female. Intestinal parasitosis had significant association with age $(\mathrm{p}=0.001)$, residence area of the patients $(\mathrm{p}=0.005)$, shoe wearing habit $(\mathrm{p}=0.000)$ and water source $(\mathrm{p}=0.048)$. However, sex was no evidence of significant association with intestinal parasitic infection $(\mathrm{p}=0.207)$ (Table 4).

\section{Prevalence of Smear Positive Tuberculosis and Intestinal Parasites Co-infection}

Intestinal parasites were detected in 24 (33.3\%) smear positive pulmonary TB patients and 96 (27.9\%) pulmonary TB negative patients. The predominant parasites detected in smear positive TB patients and TB negative patients were Hookworm 8 (11.1\%) and Ascaris lumbricoides 28 (8.2\%), respectively. (Table 5) Smear positive TB patients were frequently co-infected with parasitic infection $(\mathrm{X} 2=28.148, \mathrm{p}=0.154)$ that will increase morbidity.

\section{Discussion}

This study identified $17.3 \%$ of smear positive pulmonary tuberculosis cases. The result of this study is lowered as compared to studies conducted in Tanzania and South India, which were $81.2 \%$ and $54 \%$, respectively. Part of the differences between the prevalence in

\begin{tabular}{|c|c|c|c|}
\hline \multirow[t]{2}{*}{ Variables } & \multicolumn{2}{|l|}{ TB status } & \multirow[b]{2}{*}{$\begin{array}{l}\text { Total } \\
\mathrm{N}=415(\%)\end{array}$} \\
\hline & $\begin{array}{l}\text { Smear positive } \\
\mathrm{N}=72(\%)\end{array}$ & $\begin{array}{l}\text { Smear negative } \\
\mathrm{N}=343(\%)\end{array}$ & \\
\hline \begin{tabular}{|l|} 
Age \\
$<14$ \\
$15-29$ \\
$30-44$ \\
$>45$
\end{tabular} & $\begin{array}{l}2(0.5) \\
35(8.4) \\
23(5.5) \\
12(2.9)\end{array}$ & $\begin{array}{l}17(4.1) \\
111(26.7) \\
111(26.7) \\
104(25.1)\end{array}$ & $\begin{array}{l}19(4.6) \\
146(35.1) \\
134(32.2) \\
116(28.0)\end{array}$ \\
\hline $\begin{array}{l}\text { Sex } \\
\text { Male } \\
\text { Female }\end{array}$ & $\begin{array}{l}37(8.9) \\
35(8.4)\end{array}$ & $\begin{array}{l}195(47.0) \\
148(35.7)\end{array}$ & $\begin{array}{l}232(55.9) \\
183(44.1)\end{array}$ \\
\hline $\begin{array}{l}\text { Residence area } \\
\text { Urban } \\
\text { Rural } \\
\end{array}$ & $\begin{array}{l}22(5.3) \\
50(12.1)\end{array}$ & $\begin{array}{l}127(30.6) \\
216(52.0)\end{array}$ & $\begin{array}{l}149(35.9) \\
266(64.1)\end{array}$ \\
\hline $\begin{array}{l}\text { Religion } \\
\text { Orthodox } \\
\text { Muslim } \\
\text { Protestant } \\
\text { Catholic } \\
\end{array}$ & $\begin{array}{l}67(16.1) \\
5(1.2) \\
0(0.0) \\
0(0.0)\end{array}$ & $\begin{array}{l}296(71.3) \\
30(7.2) \\
13(3.1) \\
4(1.0)\end{array}$ & $\begin{array}{l}363(87.4) \\
35(8.4) \\
13(3.1) \\
4(1.0)\end{array}$ \\
\hline \begin{tabular}{|l} 
Marital Status \\
Single \\
Married \\
Divorced \\
Widowed \\
\end{tabular} & $\begin{array}{l}24(5.8) \\
37(8.9) \\
8(1.9) \\
3(0.7)\end{array}$ & $\begin{array}{l}104(25.1) \\
185(44.6) \\
41(9.9) \\
13(3.1)\end{array}$ & $\begin{array}{l}128(30.9) \\
222(53.5) \\
49(11.8) \\
16(3.8)\end{array}$ \\
\hline $\begin{array}{l}\text { Monthly income } \\
<200 \\
200-499 \\
500-999 \\
>1000 \\
\end{array}$ & $\begin{array}{l}35(8.4) \\
33(8.0) \\
3(0.7) \\
1(0.2)\end{array}$ & $\begin{array}{l}139(33.5) \\
132(31.8) \\
55(13.3) \\
17(4.1)\end{array}$ & $\begin{array}{l}174(41.9) \\
165(39.8) \\
58(14.0) \\
18(4.3)\end{array}$ \\
\hline $\begin{array}{l}\text { BCG Vaccination Status } \\
\text { Present } \\
\text { Absent }\end{array}$ & $\begin{array}{l}9(2.2) \\
63(15.2)\end{array}$ & $\begin{array}{l}121(29.2) \\
222(53.5)\end{array}$ & $\begin{array}{l}130(31.4) \\
285(68.7)\end{array}$ \\
\hline
\end{tabular}

TB - Tuberculosis; BCG - Bacillus Calmat and Guerin

Table 1: Socio-demographic characteristics of study participants by TB status $(\mathrm{N}=415)$, Gondar University Hospital and Poly Clinic, North West Ethiopia, 2008.

our study and other studies may be due to the difference in diagnostic methods for detecting AFB. In South India the diagnostic methods for detecting AFB were Purified Protein Derivative (PPD) and culture while, in Tanzania the diagnostic methods were both microscopy and culture $[29,30]$.

This study demonstrates that BCG vaccination status had a protective effect against tuberculosis infection, which is in line with the study conducted in Brazilian children who had been BCG vaccinated at birth (using the presence of a BCG scar as an indicator) had a significantly lower prevalence of pulmonary $\mathrm{TB}$ infection than those who had not been vaccinated [31]. BCG vaccination and monthly income had significant association with TB infectivity, however no evidence of significant relation between $\mathrm{TB}$ positivity with age and sex. This finding is in line with the study conducted in Tanzania and Gondar University Hospital [30,32].

The prevalence of $\mathrm{TB}$ and intestinal parasites co-infection was 5.7\%. This study also showed, among TB suspects studied, $28.9 \%$ had intestinal parasites. The result is lowered as compared to another hospital-based cross-sectional study conducted in Gondar University Hospital, which was $40.9 \%$ [27]. This may possibly due to the study subject differences that were TB suspects in the present study unlike known pulmonary TB patients. In this study, Hookworm was found to be the predominant intestinal parasite in smear positive TB patients; this result is concordant with the finding of other study done in South India [29]. This could be due to majority of the study subjects were came from rural areas, where shoe wearing is not a common habit. 
Citation: Alemayehu M, Birhan W, Belyhun Y, Sahle M, Tessema B (2014) Prevalence of Smear Positive Tuberculosis, Intestinal Parasites and Their Co-Infection among Tuberculosis Suspects in Gondar University Hospital and Gondar Poly Clinic, North West Ethiopia. J Microb Biochem Technol 6: 179-184. doi:10.4172/1948-5948.1000140

\begin{tabular}{|c|c|c|c|c|c|}
\hline \multirow[b]{2}{*}{ Risk factors } & \multicolumn{2}{|l|}{ TB status } & \multirow{2}{*}{$\begin{array}{l}\text { Total } \\
\mathrm{N}=415(\%)\end{array}$} & \multirow[b]{2}{*}{ P-value } & \multirow[b]{2}{*}{ OR $(95 \% \mathrm{Cl})$} \\
\hline & $\begin{array}{l}\text { Smear positive } \\
\mathrm{N}=72(\%)\end{array}$ & $\begin{array}{l}\text { Smear negative } \\
\mathrm{N}=343(\%)\end{array}$ & & & \\
\hline $\begin{array}{l}\text { Sex } \\
\text { Male } \\
\text { Female }\end{array}$ & $\begin{array}{l}37(15.9) \\
35(19.1)\end{array}$ & $\begin{array}{l}195(84.1) \\
148(80.9)\end{array}$ & $\begin{array}{l}232(55.9) \\
183(44.1)\end{array}$ & 0.396 & $0.802(0.482-1.335)$ \\
\hline $\begin{array}{l}\text { Residence ar } \\
\text { Urban } \\
\text { Rural }\end{array}$ & $\begin{array}{l}22(14.8) \\
50(18.8)\end{array}$ & $\begin{array}{l}127(85.2) \\
216(81.2)\end{array}$ & $\begin{array}{l}149(35.9) \\
266(64.1)\end{array}$ & 0.290 & $0.745(0.431-1.288)$ \\
\hline $\begin{array}{c}\text { BCG Vaccina } \\
\text { Present } \\
\text { Absent }\end{array}$ & $\begin{array}{l}9(6.9) \\
63(22.1)\end{array}$ & $\begin{array}{l}121(93.1) \\
222(77.9)\end{array}$ & $\begin{array}{l}130(31.4) \\
285(68.7)\end{array}$ & 0.000 & $0.262(0.126-0.545)$ \\
\hline $\begin{array}{l}\text { Previous TB } \\
\text { Yes } \\
\text { No }\end{array}$ & $\begin{array}{l}21(20.8) \\
51(16.2)\end{array}$ & $\begin{array}{l}80(79.2) \\
263(83.8)\end{array}$ & $\begin{array}{l}101(24.3) \\
314(75.7)\end{array}$ & 0.294 & $1.354(0.768-2.385)$ \\
\hline $\begin{array}{l}\text { Shoe wearing } \\
\text { Yes } \\
\text { No }\end{array}$ & $\begin{array}{l}51(15.4) \\
21(25.0)\end{array}$ & $\begin{array}{l}280(84.6) \\
63(75.0)\end{array}$ & $\begin{array}{l}331(79.8) \\
84(20.2)\end{array}$ & 0.038 & $0.546(0.307-0.973)$ \\
\hline $\begin{array}{l}\text { Soap usage } \\
\text { Yes } \\
\text { No }\end{array}$ & $\begin{array}{l}17(13.9) \\
55(18.8)\end{array}$ & $\begin{array}{l}105(86.1) \\
238(81.2)\end{array}$ & $\begin{array}{l}122(29.4) \\
293(70.6)\end{array}$ & 0.236 & $0.701(0.388-1.264)$ \\
\hline $\begin{array}{l}\text { Fingernail } \\
\text { Trimmed } \\
\text { Untrimmed }\end{array}$ & $\begin{array}{l}15(11.6) \\
57(19.9)\end{array}$ & $\begin{array}{l}114(88.4) \\
229(80.1)\end{array}$ & $\begin{array}{l}129(31.1) \\
286(68.9)\end{array}$ & 0.039 & $0.529(0.287-0.974)$ \\
\hline
\end{tabular}

TB - Tuberculosis; BCG - Bacillus Calmat and Guerin; OR - Odds Ratio

Table 2: Tuberculosis infection and associated risk factors among 415 tuberculosis suspects attending Gondar University Hospital and Poly Clinic, North West Ethiopia, 2008 .

\begin{tabular}{|l|l|l|}
\hline $\begin{array}{l}\text { Intestinal Parasites Identified } \\
\text { Helminthes }\end{array}$ & Frequency \\
\hline Hookworm & 32 & Percent \\
\hline Strongloidis stercolaris & 26 & 7.7 \\
\hline Schistosoma mansoni & 11 & 6.3 \\
\hline Trichuris trichuria & 10 & \\
\hline Hyminolepis nana & 3 & \\
\hline Taenia species & 3.7 \\
\hline $\begin{array}{l}\text { Protozoans } \\
\text { Entamoeba histolytica cyst }\end{array}$ & 1 & \\
\hline Entamoeba histolytica trophozoite & 6.4 \\
\hline Giardia lamblia cyst & 6 \\
\hline Giardia lamblia trophozoite & 5 \\
\hline Mixed parasitic infection & 0.7 \\
\hline Overall & 4 \\
\hline
\end{tabular}

Table 3: Prevalence of intestinal parasites among 415 tuberculosis suspects attending Gondar university hospital and poly clinic, Northwest Ethiopia, 2008.

\begin{tabular}{|c|c|c|c|c|c|}
\hline Variables & Intestinal parasite Positive $\mathrm{N}=120(\%)$ & Intestinal parasite negative $\mathbf{N}=\mathbf{2 9 5}(\%)$ & Total $\mathrm{N}=415(\%)$ & p-value & Pearson X2 \\
\hline $\begin{array}{l}\text { Age } \\
<14 \\
15-29 \\
30-44 \\
>45\end{array}$ & $\begin{array}{l}11(2.7) \\
47(11.3) \\
34(8.2) \\
28(6.8)\end{array}$ & $\begin{array}{l}8(1.9) \\
99(23.9) \\
100(24.1) \\
88(21.2)\end{array}$ & $\begin{array}{l}19(4.6) \\
146(35.2) \\
134(32.3) \\
116(28.0)\end{array}$ & 0.001 & 257.272 \\
\hline Sex & & & & 0.207 & 25.984 \\
\hline Male & $64(15.4)$ & $168(40.5)$ & $232(55.9)$ & & \\
\hline Female & $56(13.5)$ & $127(30.6)$ & $183(44.1)$ & & \\
\hline Residence area & & & & 0.005 & 41.172 \\
\hline Urban & $30(7.3)$ & $119(28.7)$ & $149(36.0)$ & & \\
\hline Rural & $90(21.7)$ & $176(42.4)$ & $266(64.1)$ & & \\
\hline Shoe wearing & & & & 0.000 & 49.133 \\
\hline Yes & $79(19.0)$ & $252(60.7)$ & $331(79.7)$ & & \\
\hline No & $41(9.9)$ & $43(10.4)$ & $84(20.3)$ & & \\
\hline Water source & & & & 0.048 & 130.278 \\
\hline Pipe & $36(8.7)$ & $134(32.3)$ & $170(41.0)$ & & \\
\hline Protected spring \& well & $13(3.1)$ & $24(5.8)$ & 37 (8.9) & & \\
\hline Unprotected spring \& well & $53(12.8)$ & $102(24.6)$ & $155(37.4)$ & & \\
\hline River & $18(4.3)$ & $35(8.4)$ & $53(12.7)$ & & \\
\hline
\end{tabular}

Table 4: Associated risk factors for intestinal parasitic infection among tuberculosis suspects attending Gondar University hospital and poly clinic, Northwest Ethiopia, 2008. 
Citation: Alemayehu M, Birhan W, Belyhun Y, Sahle M, Tessema B (2014) Prevalence of Smear Positive Tuberculosis, Intestinal Parasites and Their Co-Infection among Tuberculosis Suspects in Gondar University Hospital and Gondar Poly Clinic, North West Ethiopia. J Microb Biochem Technol 6: 179-184. doi:10.4172/1948-5948.1000140

\begin{tabular}{|l|l|l|}
\hline \multirow{2}{*}{ Intestinal Parasites Identified } & $\begin{array}{l}\text { TB status } \\
\text { Smear positive }\end{array}$ & Smear negative N (\%) \\
\hline Helminthes & & \\
Ascaris lumbricoides & $4(5.6)$ & $28(8.2)$ \\
\hline Hookworm & $8(11.1)$ & $18(5.2)$ \\
\hline Strongloidis stercolaris & $5(6.9)$ & $6(1.7)$ \\
\hline Schistosoma mansoni & $3(4.2)$ & $7(2.0)$ \\
\hline Trichuris trichuria & $1(1.4)$ & $2(0.6)$ \\
\hline Hyminolepis nana & $0(0.0)$ & $3(0.9)$ \\
\hline Taenia species & $0(0.0)$ & $1(0.3)$ \\
\hline Protozoans & & \\
\hline Entamoeba histolytica cyst & $0(0.0)$ & $6(1.7)$ \\
\hline Entamoeba histolytica trophozoite & $0(0.0)$ & $5(1.5)$ \\
\hline Giardia lamblia cyst & $1(1.4)$ & $3(0.9)$ \\
\hline Giardia lamblia trophozoite & $0(0.0)$ & $2(0.6)$ \\
\hline Mixed parasitic infection & $2(2.8)$ & $15(4.3)$ \\
\hline Overall & $24(33.3)$ & $96(27.9)$ \\
\hline
\end{tabular}

operation and material support. We would like to gratefully acknowledge the study participants without whom this work would have not been a reality. We also acknowledge the staff nurses working in the medical outpatient department and staffs to the clinical Laboratory of the University of Gondar hospital for their support during data collection and sample processing

\section{References}

1. WHO (2011) Global Tuberculosis control report: World Health Organization Geneva: WHO, 2011.

2. Kumar V, Abbas AK, Fausto N, Mitchell RN (2007) Robbins Basic Pathology Saunders Elsevier 8th edition: 516-522.

3. Federal Ministry of Health Ethiopia (2008) Tuberculosis, leprosy and TB/HIV prevention and control programme manual, 4th edition: 5-57.

4. Acocella G, Nonis A, Perna G, Patane E, Gialdroni-Grassi G, Grassi C (1988) Comparative bioavailability of isoniazid, rifampin, and pyrazinamide administered in free combination and in a fixed triple formulation designed for daily use in antituberculosis chemotherapy. II. Two-month, daily administration study. Am Rev Respir Dis 138:886-890.

5. Ellard GA, Ellard DR, Allen BW, Girling DJ, Nunn AJ, et al. (1986) The bioavailability of isoniazid, rifampin, and pyrazinamide in two commercially available combined formulations designed for use in the short-course treatment of tuberculosis. Am Rev Respir Dis 133: 1076-1080.

TB - Tuberculosis

Table 5: Type and frequency of intestinal parasites among TB suspects by TB status at Gondar University hospital and Poly Clinic, Northwest Ethiopia, 2008.

\section{Limitations of the Study}

Different immunological parameters were not performed to show the role of parasitic infestation in the pathogenesis of tuberculosis and lack of mycobacterial culture in our study, reduces the number of TB bacilli to determine the rates of TB disease.

\section{Conclusion}

The prevalence of smear positive $\mathrm{TB}$ and intestinal parasite infection among $\mathrm{TB}$ suspects in Gondar was $17.3 \%$ and $28.9 \%$, respectively. Smear positive TB and intestinal parasite co-infection prevalence was 5.7\% and the prevalence of Hookworm infection is relatively higher in smear positive TB patients that may increase morbidity. Tuberculosis had significant association with monthly income and BCG vaccination. Age, residence area, shoe wearing habit and water source had significant association with intestinal parasitic infection. Therefore, all TB suspects in areas where TB and intestinal parasites are co-endemic should be checked for parasite infections and be treated accordingly to reduce further complications. Further case control studies need to be done to examine the association between intestinal helminthes infection and active tuberculosis. In addition, helminthes impair resistance against a number of infections of major public health importance, including TB. The interactions should be studied in the design of vaccines against these diseases.

\section{Authors' contributions}

Martha Alemayehu: conception of the research idea, study design, data collection and analysis, interpret the data and writing the manuscript; Wubet Birhan, Yeshambel Belyhun: study design, data collection, entry, part of laboratory work, data analysis and drafting the manuscript; Mezgebu Sahle, Belay Tessema: helped in the statistical analysis, interpretation and reviewed the manuscript. All authors have read and approved the final manuscript.

\section{Conflict of Interest}

The authors declare that they have no competing interests

\section{Acknowledgements}

We would like to thank the Department of Medical Laboratory Technology and Department of Medical Microbiology, University of Gondar for their kind co-

6. Choudhri SH, Hawken M, Gathua S, Minyiri GO, Watkins W, et al. (1997) Pharmacokinetics of antimycobacterial drugs in patients with tuberculosis AIDS, and diarrhea. Clin Infect Dis 25: 104-111.

7. Gordon SM, Horsburgh CR Jr, Peloquin CA, Havlik JA Jr, Metchock B, et al. (1993) Low serum levels of oral antimycobacterial agents in patients with disseminated Mycobacterium avium complex disease. J Infect Dis 168: 15591562.

8. Sahai J, Gallicano K, Swick L, Tailor S, Garber G, et al. (1997) Reduced plasma concentrations of antituberculosis drugs in patients with HIV infection. Ann Intern Med 127: 289-293.

9. Taylor B1, Smith PJ (1998) Does AIDS impair the absorption of antituberculosis agents? Int J Tuberc Lung Dis 2: 670-675.

10. UNICEF (1993) The prescriber: 1-8.

11. Tesfamichael T, kloos H: Intestinal Parasitism. In: Zein AZ and KlooSH (1988) The Ecology of Health and Disease in Ethiopia, Addis Ababa: Ministry of Health 210-216.

12. World Health Organization (1991) Basic Laboratory Methods in Medica parasitology. WHO Report. Geneva, Switzerland: WHO, 25-26.

13. Savioli LM, YU Sen Hai (1996) Intestinal Worms. World Health Organization 4: 26-29.

14. Berhanu E, Shibru T (1993) Intestinal helminth infection at Zeghie, Ethiopia with Emphasis on schistosomiasis mansoni. Ethiop J Health Dev 7: 21-24.

15. Tadesse G (2005) The Prevalence of intestinal helminthic infections and associated risk factors among school children in Babile town, Eastern Ethiopia Ethiop J Health Dev 19: 140-147.

16. Bentwich Z, Horner R, Borkow G (2010) De-Worming in Developing Countries as a Feasible and Affordable Means to Fight Co-Endemic Infectious Diseases. Open Biology Journal 3:97-103.

17. Bourke CD, Maizels RM, Mutapi $F$ (2011) Acquired immune heterogeneity and its sources in human helminth infection. Parasitology 138: 139-159.

18. Sheriff FG, Manji KP, Manji MP, Chagani MM, Mpembeni RM, et al. (2010) Latent tuberculosis among pregnant mothers in a resource poor setting in Northern Tanzania: a cross-sectional study. BMC Infect Dis 10: 52.

19. Chan J and Kaufmann SHE: Immune mechanism of protection (1994) In Tuberculosis Pathogenesis, Protection and control Edited by Bloom BR Washington DC: American Society for Microbiology 389-411.

20. Gonzalez-Juarrero M, Turner OC, Turner J, Marietta P, Brooks JV, et al. (2001) Temporal and spatial arrangement of lymphocytes within lung granulomas induced by aerosol infection with Mycobacterium tuberculosis. Infect Immun 69: $1722-1728$.

21. Kaufmann SH (2002) Protection against tuberculosis: cytokines, T cells, and macrophages. Ann Rheum Dis 61 Suppl 2: ii54-58. 
Citation: Alemayehu M, Birhan W, Belyhun Y, Sahle M, Tessema B (2014) Prevalence of Smear Positive Tuberculosis, Intestinal Parasites and Their Co-Infection among Tuberculosis Suspects in Gondar University Hospital and Gondar Poly Clinic, North West Ethiopia. J Microb Biochem Technol 6: 179-184. doi:10.4172/1948-5948.1000140

22. Bentwich Z, Kalinkovich A, Weisman Z (1995) Immune activation is a dominant factor in the pathogenesis of African AIDS. Immunol Today 16: 187-191.

23. Elias D, Akuffo $H$, Britton S (2006) Helminthes could influence the outcome of vaccines against TB in the tropics. Parasite Immunol 28: 507-513.

24. Bentwich Z, Kalinkovich A, Weisman Z, Borkow G, Beyers N, et al. (1999) Can eradication of helminthic infections change the face of AIDS and tuberculosis? Immunol Today 20: 485-487.

25. Borkow G, Weisman Z, Leng Q, Stein M, Kalinkovich A, et al. (2001) Helminths, human immunodeficiency virus and tuberculosis. Scand J Infect Dis 33: 568571.

26. Fincham JE, Markus MB, Adams VJ (2003) Could control of soil-transmitted helminthic infection influence the HIVIAIDS pandemic. Acta Trop 86: 315-333.

27. Kassu A, Mengistu G, Ayele B, Diro E, Mekonnen F, et al. (2007) HIV and intestinal parasites in adult TB patients in a teaching hospital in Northwest Ethiopia. Trop Doct 37: 222-224.
28. [No authors listed] (1994) Expanded programme on immunization. Programme review. Wkly Epidemiol Rec 69: 87-90.

29. Lipner EM, Gopi PG, Subramani R, Kolappan C, Sadacharam K, et al. (2006) Coincident filarial, intestinal helminth, and mycobacterial infection: helminths fail to influence tuberculin reactivity, but BCG influences hookworm prevalence. Am J Trop Med Hyg 74: 841-847.

30. Range N, Magnussen P, Mugomela A, Malenganisho W, Changalucha J, et al. (2007) HIV and parasitic co-infections in tuberculosis patients: a crosssectional study in Mwanza, Tanzania. Ann Trop Med Parasitol 101: 343-351.

31. Resende Co T, Hirsch CS, Toossi Z, Dietze R, Ribeiro-Rodrigues R (2007) Intestinal helminth co-infection has a negative impact on both antiMycobacterium tuberculosis immunity and clinical response to tuberculosis therapy. Clin Exp Immunol 147: 45-52.

32. Kassu A, Mohammad A, Fujimaki Y, Moges F, Elias D, et al. (2004) Serum IgE levels of tuberculosis patients in a tropical setup with high prevalence of HIV and intestinal parasitoses. Clin Exp Immunol 138: 122-127. 